\title{
The turn-of-the-month effect in Pakistani stock market
}

\author{
Muhammad Sarmad Irtiza', Shahbaz Khan ${ }^{1 *}$, Nida Baig², Syed Muhammad Ali Tirmizi and Ilyas Ahmad ${ }^{3}$
}

\begin{abstract}
This research intends to explore the presence of the "turn-of-the-month-effect (TOME)" in the Pakistani stock market. The TOME is the temporary increase in prices of registered shares on the last operating day of the month and the initial 3-4 days of the following month. The selection incorporates the secondary data, which comprises the ending prices of the "KSE-100 Index" for 2013-2018. Contrary to the previous evidence in Pakistan, we run an in-depth yearwise analysis and report an interesting fact that the TOME is significant only during 2013-2016, while it vanishes for 2017 and 2018. We suggest that the "turn-of-the-month" anomaly may disappear during stock market crisis times. The research contains significant importance for potential shareholders because a rational shareholder considers several measures while making his investment decisions and constructing hedging strategies.
\end{abstract}

Keywords: Turn-of-the-month-effect, KSE-100 Index, Calendar anomalies, Efficient market hypothesis

JEL Classifications: G1, G10, G140

\section{Introduction}

An anomaly is a significant challenge for the academic world because of its irregularity. It is a weird or an occasional matter in a non-contributing world. In the stock exchange, an anomaly causes divergence in the group of stocks, which results in inconsistency with the efficient market hypothesis. Due to the steady release and fast spread of new information, in some cases, efficient markets are challenging to accomplish and sometimes more hard to maintain. The presence of these abnormalities is against the standards of market efficiency because it may offer unusual monetary awards to the financial specialists.

Given the above observable postulate, some of stock market's abnormalities remain persistently, while rest of them show an instantaneous pattern. For instance, the "day of the week effect" suggests that the returns of stocks will, in general, be the highest on a specific day of the

\footnotetext{
*Correspondence: shahbaz.khans@yahoo.com

1 Faculty of Management Sciences, Foundation University Islamabad, Islamabad, Pakistan

Full list of author information is available at the end of the article
}

week. The "month of the year effect" and, specifically, the January impact shows that profits are more outstanding in January. The monthly effect intimates that throughout the primary half of the month, the average returns for the stocks are certain and greater than the other half of the month.

The significant anomaly considered in this study is the "turn-of-the-month-effect (TOM)," which is one of the most compelling and simultaneously the oldest price anomaly in the financial market but has not yet fully understood [41]. The average returns for the stocks at the "turn-of-the-month" is considerably more significant than the daily returns in the other days [17]. The "turnof-the-month-effect" implies that maximum profits are accomplished on the turning days of the schedule [3].

Globally, various international stock markets show the evidence for the presence of the "turn-of-the-montheffect" [11, 20, 25, 36]. Practically, the straightforward purchasing of shares in the last few days of the month and then selling those again in the first three to four days of the new month refers to the "turn-of-the-montheffect" $[6,14]$. This trading activity leads towards a buoyant in the stock prices on the first three business days 
of the month and the last business day of the preceding month. More specifically, stock market displays better returns during the "turn-of-the-month" period than for the "rest-of-the-month" period $[5,6]$.

The study conducts an exploratory analysis to confirm the existence of the "turn-of-the-month" effect, which may contribute in a couple of ways. First, we extend the empirical evidence to the earlier studies on the calendar anomalies in the Pakistani Stock Market by exclusively focusing on the "turn-of-the-month-effect." We can notice scarce literature exploring the influence of different calendar anomalies on the stock market of Pakistan (e.g., $[4,16,32])$. This study uses a more recent sample period (2013-2018) and updates the previous literature findings. Last but not least, we run an in-depth analysis to make our work novel in the Pakistani setting. We first present a preliminary analysis year-wise and month-wise for the effect of the turn-of-the-month period and then run a linear regression model to robust check our maiden findings.

The rest of the paper organizes as below: following the motivation to select the Pakistani stock market, section "Review of literature" includes a complete review of the latest and relevant literature available on the topic; section "Methods" presents the methodology to test "turn-of-the-month-effects" in the Stock market of Pakistan; section "Results and discussion" incorporates the experimental analysis, critical discoveries of the study and evaluation; and finally section "Conclusions" comprehensively concludes the research.

\section{Why Pakistani stock market is an interesting case?}

Pakistan is a developing country along with a volatile political environment. We usually see it fighting with war and terror. Also, it is exposed towards a greater climatic risk, but still, the stock market of Pakistan has always shown an excellent performance. Even in pandemic times, it is performing well relative to the rest of the world. Khaleej Times, in its newspaper, described that the worth of Pakistan provided $26 \%$ of returns for the US Dollar Shareholders since 2009, which made Karachi stock exchange the best working capital market in the world. In 2016, Bloomberg ranked the index of Pakistan as the fifth best performing stock in the world. Interestingly, the stock market was declared the worst performer in Asia in the very next year [33]. That is why the Pakistani stock market is a source of attraction not only for developing countries but for the developed nations as well. Thus, investors, policymakers, academicians, and economists are usually concerned about exploring its anomalies. So, it is pretty exciting and informative to study the different peculiarities of a developing nation top-performing stock market.

\section{Review of literature}

Calendar anomalies, including the "turn-of-the-montheffect," cause volatility in the financial markets. In this way, it's an ideal opportunity to see the reaction of the stock markets. As indicated by the assumptions of the Efficient Market Hypothesis, all the financial specialists are rational. When the "turn-of-the-month-effect" strikes the stock exchange, it quickly grasps and alters its understanding. According to Fama [13], there are the following three types of Efficient Market Hypothesis:

- Strong form of EMH

- Semi Strong from EMH

- Weak form of EMH

The market is strong-form efficient if costs reflect a wide range of data, whether accessible freely or secretly, and semi-strong efficient if the stock prices immediately reflect any new openly accessible data. Where a weak form of efficiency characterizes that "current prices completely reflect all data contained in historical prices," meaning no financial specialist can set up an exchanging rule dependent on past price patterns to gain abnormal returns [31]".

\section{Turn-of-the-month-effect and Stock Market Returns}

Like the various other calendar anomalies, including "day-of-the-week-effect [38]", the "turn-of-the-yeareffect [4]", the "Halloween-effect [30]", the "January-effect [4]", and the "Holiday-Effect [12]" etc., the "turn-of-themonth-effect $[1,11,18,26,35]$ ", also has a significant influence on the stock market.

Dated back to the study of Ariel [6], who first investigated the existence of the "turn-of-the-month-effect" in the US stock market. After examining a sample period of 19 years (1963-1981), he found significantly higher stock returns on the final trading day of the previous month and the first four trading days of the following month. Later on, Kohers and Patel [19] found a new "turn-of-the-month" significant pattern in the Standard \& Poor's regular returns and the NASDAQ indices. They divided a month into three parts and found that in the first-third, the profits are the most elevated. In the second-third, returns experienced a fall, and in the last-third of a month, the returns are least and most of the time negative.

Ample evidence has confirmed the presence of the "turn-of-the-month-effect" by taking a sample from multiple countries. For instance, Cadsby and Ratner [11] found the existence of the "turn-of-the-month-effect" in 
West Germany, United Kingdom, Switzerland, Canada and Australia. Using parametric and nonparametric tests, Kunkel et al. [20] analyzed a selection of different European and Far East countries and reported the existence of the "turn-of-the-month" behavior in sixteen out of nineteen international stock markets. Mcconnell and Xu [26] investigated a sample of 34 countries and found support for the "turn-of-the-month effect". Similarly, Martikainen et al. [25] tested a sample of twenty-four regions of the world and found that most of the world's stock markets exhibited this anomaly, however, they either failed to see or noticed weak evidence in smaller-sized stock markets. They further observed higher returns on -1 day than other "turn-of-the-month" days. In their more recent work, Aziz and Ansari [8] also investigated a broader sample of twelve Asia-pacific markets to confirm the "turn-of-the-month-effect". They found evidence of the "turn-of-the-month-effect" anomaly in 11 out of 12 stock markets, and this effect was more prominent in South Korea, India, Pakistan, Philippines, and China.

Plethora of work has also investigated the single country index returns to investigate the existence of the "turnof-the-month-effect". Li-Cheng [22], for example, found solid proof of the "turn-of-the-month-effect" in Chinese stock exchanges. Based on a sample drawn from two major stock exchanges, Shanghai and Shenzhen, they found that average returns are greater from the last day of the preceding month to the sixth business day of the following month. McGuinness [27] found evidence of a persistent "turn-of-the-month-effect" in the Hong Kong stock market. He recorded that the estimated returns between the last trading day in a scheduled month and the successive close five days of business later reach up to $1.5 \%$ levels as compared to average returns of $-0.3 \%$ for the prior 5-days period of "turn-of-the-month-effect." Based on a sample of the "Istanbul Stock Exchange (ISE), Oguzsoy and Guven [29] presented proof of the presence of the "turn-of-the-month-effect" in the Istanbul Stock Exchange (ISE) for the phase between 1988 and 1999. The mean returns during the "turn-of-the-month" days are radically lower than the expected returns for the rest of the month. The outcomes are measurably significant at the 1\% level for the index. Mangala and Sharma [24] provided a solid evidence of the presence of the "turn-of-the-month-effect" in Indian stock market. Silva [34] investigated a sample of Portuguese stock returns to check the presence of different calendar "anomalies." He discovered that the "turn-of-the-month-effect" was economically more significant than statically. Vasileiou [37] proposed that, there is a solid tendency for the "turnof-the-month-effect". Also, the financial trend and the uncertainty shifts control the "turn-of-the-month-effect" and the "turn-of-the-month" days do not give negative returns even during long haul periods. In addition, this perspective may cover the way for another clarification concerning why the "turn-of-the-month-effect" fades of persistence through time.

From Pakistani perspective, Jebran and Chen [16] found a significant support for the presence of various calendar anomalies, including, "turn-of-the-montheffect" in an Islamic equity market of Pakistan. Similarly, Quayyoum et al. [32] confirmed the presence of "monthly effect" in Pakistan stock exchange (PSX). In his more recent work, Anjum [4] found empirical support for the existence three different market abnormalities, including "day of the week effect", monthly effect, and the weekend effect in PSX.

Contrary to the existence of the "turn-of-the-montheffect", there are some studies finding weak or no evidence of the said phenomenon. For instance, Wong et al. (2006) were unable to find the presence of different calendar anomalies, including the "turn-of-the-month-effect" in the Singapore stock market. Similarly, Arsad et al. [7] found weak empirical support for the presence of the "turn-of-the-month-effect" in various stock markets. In another study, Al-Jarrah et al. [2] examined the existence of the "turn-of-the-month-effect" in the Amman Stock Exchange and found no significant evidence. The outcomes of their study stipulated that the acknowledged returns from trading in the beginning of the month are not measurably higher than the returns acknowledged from trading in the remainder of the month.

The evidence on the presence of the "turn-of-themonth-effect" is somewhat mixed, as apparent from the above discussion. Therefore, we provided a further exploratory examination for the "turn-of-the-month" anomaly in the "KSE-100" index. The study extended the empirical evidence by exclusively focusing on the "turnof-the-month-effect" in the Pakistani stock market. In addition, the study uses a more recent sample period for 2013-2018 and employs an in-depth analysis to make our work novel in the Pakistani setting. We first present a preliminary analysis year-wise and month-wise for the effect of the turn-of-the-month period and then run a linear regression model to robust check our maiden findings.

\section{Liquid fund theory}

Enhanced liquidity may be an essential determinant for the occurrence of the "turn-of-the-month-effect" $[28,40]$. The reasons for the liquidity pump in the stock market might include the regularity of the payment framework in the financial system that leads to generating excess cash flows at the turn of each scheduled month [28]. For instance, according to a research report by Moody's, cited in Zhang [39], the corporate-and municipal bonds make 
their interest-and principal payments at the last or first trading day of each calendar month, which in turn bring about an adequate amount of cash receipts in the hands of investors. In addition, payment of salaries near the end of each calendar month (aligned with the last trading day of the stock market in each calendar month) becomes a significant factor in the availability of ready funds [9]. Accordingly, intending to generate higher returns in the short-run [10], the investors quickly reinvest their earnings into more liquid stocks rather than fixed deposits, which causes a surge in the stock returns at the turn of each scheduled month $[9,28]$.

Empirically, plethora of researchers reported that increased liquidity is one of the significant reasons for stock market to gain momentum at the "turn-of-themonth" (for example, see studies by [9, 11, 18, 21, 23].

\section{Methods}

In this section, we provide the depiction of data, the research design, and data analysis in conducting the study.

\section{Definition of variables}

\begin{tabular}{|c|c|c|c|}
\hline Variable & Notation & Description & Source \\
\hline $\begin{array}{l}\text { Turn-of-the- } \\
\text { month } \\
\text { dummy }\end{array}$ & TMD & $\begin{array}{l}\text { TMD is a dummy variable } \\
\text { for "turn-of-the-month- } \\
\text { effect", which takes the } \\
\text { value = 1, if KSE-100 } \\
\text { returns lie within "turn- } \\
\text { of-the-month" period; } \\
\text { otherwise =0 }\end{array}$ & $\begin{array}{l}\text { Author's own } \\
\text { computation in } \\
\text { MS Excel }\end{array}$ \\
\hline $\begin{array}{l}\text { KSE-100 } \\
\text { Index } \\
\text { Returns }\end{array}$ & KSEIR & $\begin{array}{l}\text { Stock returns are the } \\
\text { profits generated from } \\
\text { the Stock Exchange by } \\
\text { the shareholders. Using } \\
\text { the closing stock prices } \\
\text { of "KSE-100 Index", we } \\
\text { calculate these returns } \\
\text { by using the following } \\
\text { formula: } \\
R=\left(P_{t}-P_{t-1}\right) / P_{t-1}\end{array}$ & Yahoo Finance \\
\hline $\begin{array}{l}\text { Turn-of-the- } \\
\text { month } \\
\text { prices }\end{array}$ & PT & $\begin{array}{l}\text { These are stock prices } \\
\text { of the organizations } \\
\text { listed at the KSE during } \\
\text { the four business days } \\
\text { forming a "turn-of-the- } \\
\text { month-effect" }\end{array}$ & Yahoo Finance \\
\hline $\begin{array}{l}\text { Non turn-of- } \\
\text { the-month } \\
\text { prices }\end{array}$ & PNT & $\begin{array}{l}\text { These are stock prices of } \\
\text { the organizations listed } \\
\text { at the KSE, other than } \\
\text { four days of the month }\end{array}$ & Yahoo Finance \\
\hline
\end{tabular}

Notes: This table reports the definition of variables. Here, "Turn-of-the-montheffect" is our independent variable which is measured by a Turn-of-the-month dummy and "KSE-100 Index Returns" is our dependent variable, where stock returns are the profits generated from the Stock Exchange by the shareholders. Also, PT and PNT demonstrate the prices of organizations listed at KSE during the four business days and the remaining days of the month, respectively.The setting
The Karachi Stock Exchange (KSE), situated in Karachi, Sindh, Pakistan was established in 1947 and made liable for posting firms and exchanging of offers by securing investors' wealth. It has now been integrated in the Pakistan Stock Exchange, alongside the Lahore Stock Exchange (LSE) and Islamabad Stock Exchange (ISE). It was Pakistan's sole conventional stock exchange to give monetary data of recorded firms to the financial specialists and one of the most seasoned stock trades in South Asia. As indicated by Bloomberg, the Pakistani benchmark stock exchange index is the third-best presenter on the planet since 2009. The KSE was considered among the 10 best stock exchanges on the planet. Business days are from Monday to Friday.

\section{Index characteristics}

We investigated the impact of "turn-of-the-month" on "KSE-100 Index". "KSE-100 Index" is the main index of Pakistan stock exchange which consists of top 100 companies' stocks. "KSE-100 Index" depends on the freefloating strategy that implies just shares, that are openly exchanged, will be added in the evaluation of the index values.

\section{Data collection}

To gather data on daily returns of "KSE-100 Index", we use "Yahoo Finance" as a sourcing reservoir. We included 6 years of data from the period of 2nd January, 2013 till 31st December, 2018 and daily stock returns were determined using closing prices of "KSE-100 Index". The examination is an all-inclusive effort to explore the "turnof-the-month-effect" across Pakistan stock market. Also, the misplaced values of data were acquired through utilizing the formulas of interpolation. So with that, 1505 observations were obtained for this study.

\section{Unit of analysis}

We will run our analysis on daily stock return. So, each stock return of the "KSE-100 Index" would be counted as our unit of analysis.

\section{Hypothesis}

The null hypothesis is Ho: TOMR $=$ ROMR and the alternate hypothesis is: $\mathrm{H} 1$ : $\mathrm{TOMR} \neq \mathrm{ROMR}$, where TOMR represents the returns in the "turn-of-the-month" period and ROMR represents the returns in "rest-of-the-month" period. The null hypothesis (Ho) focused on demonstrating that there is no considerable change in returns at the end and start of the month as compared to other days of the month. The alternate hypothesis $(\mathrm{H} 1)$ is focused on giving proof of progress in returns during the 
"turn-of-the-month" period when compared with the other business days of the month.

\section{KSE-100 Index returns}

We use daily stock prices of "KSE-100 Index" for the period between January 2013 and December 2018. We use following equation to calculate daily KSE-100 returns:

$$
\mathrm{KSE}_{100} R_{t}=\frac{\left(P_{t}-P_{t-1}\right)}{P_{t-1}}
$$

where $\mathrm{KSE}_{100} R_{t}$ indicates daily stock return of "KSE-100 Index", $P_{t}$ represents the closing stock price at time $t$, and $P_{t-1}$ denotes closing price of stock at time $t-1$.

\section{Turn-of-the-month period}

"Turn-of-the-month-effect" is associated with the regularity of payments, which causes a prominent addition of liquidity and stock returns towards the completion of each schedule month. This effect indicates incompetency inside business sectors. Regardless of the way that the impact is gradually segmented among minimal-cap and low-esteem stocks; moreover, it exists for large-cap and high-cost stocks. In stock market, tested anomalies appear to survive, and these transparently mesmerize many investors. While these inconsistencies are worth exploring, investors should remember this injunctionanomalies can show up, vanish, and re-appear with virtually no attention.

The "turn-of-the-month-effect" is regularly characterized as the period crossing the last day of preceding month and the initial some days of the next month [6, 18].

As our examination likewise includes a month-bymonth investigation of the "turn-of-the-month-effect", it is critical to explain how the "turn-of-the-month" period for various months is marked. We allude to every "turnof-the-month" phase with the name of month that it prompts, more willingly than the month that it closes. For example, the period that comprises the last business days of December and the initial business days of January, will be pointed out to as the January "turn-of-the-month" period rather than the December "turn-of-the-month" period.

Following graphs explain the trend of monthly returns in the last 5 days of preceding month and first 5 days of the next month to explore that how turn-of-the-month period effects the returns of KSE.

As evident from Figs. 1, 2, 3 and 4, the stock returns rise on the last business day and the initial three business days of the months for 2013-2016, indicating the existence of "turn-of-the-month-effect" in "KSE-100 Index". On the other hand, we cannot notice any increase in

\section{Turn of The Month Returns During Year 2013}

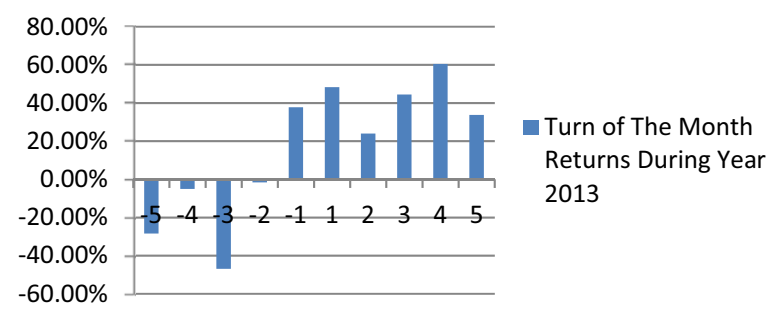

Fig. 1 TOM period during 2013
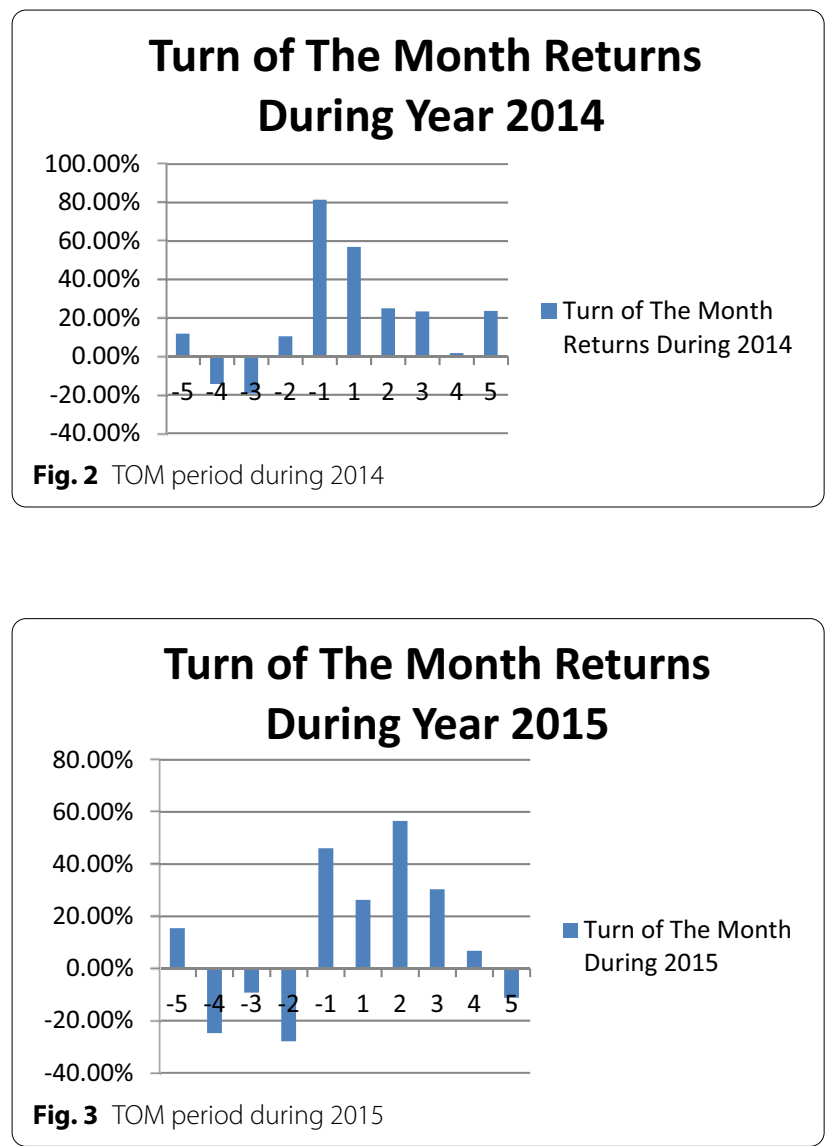

stock returns during 2017 and 2018. To further reconfirm our trend analysis, we run the t-test of means and regression analysis and find similar results again (Figs. 5, 6).

\section{Econometric equation}

$$
\mathrm{KSE}_{100} R=\alpha+\beta \mathrm{TMD}+\mu
$$




\section{Turn of The Month Returns During Year 2016}

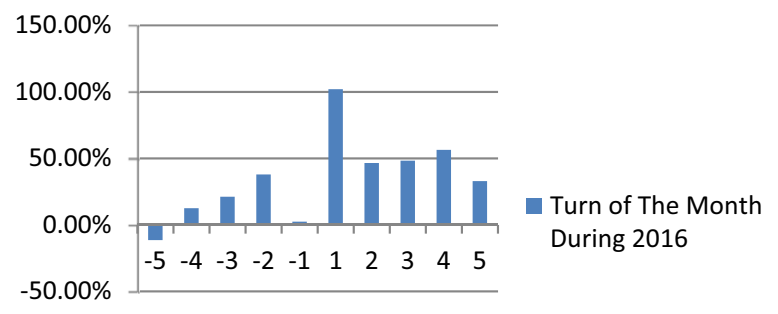

Fig. 4 TOM period during 2016
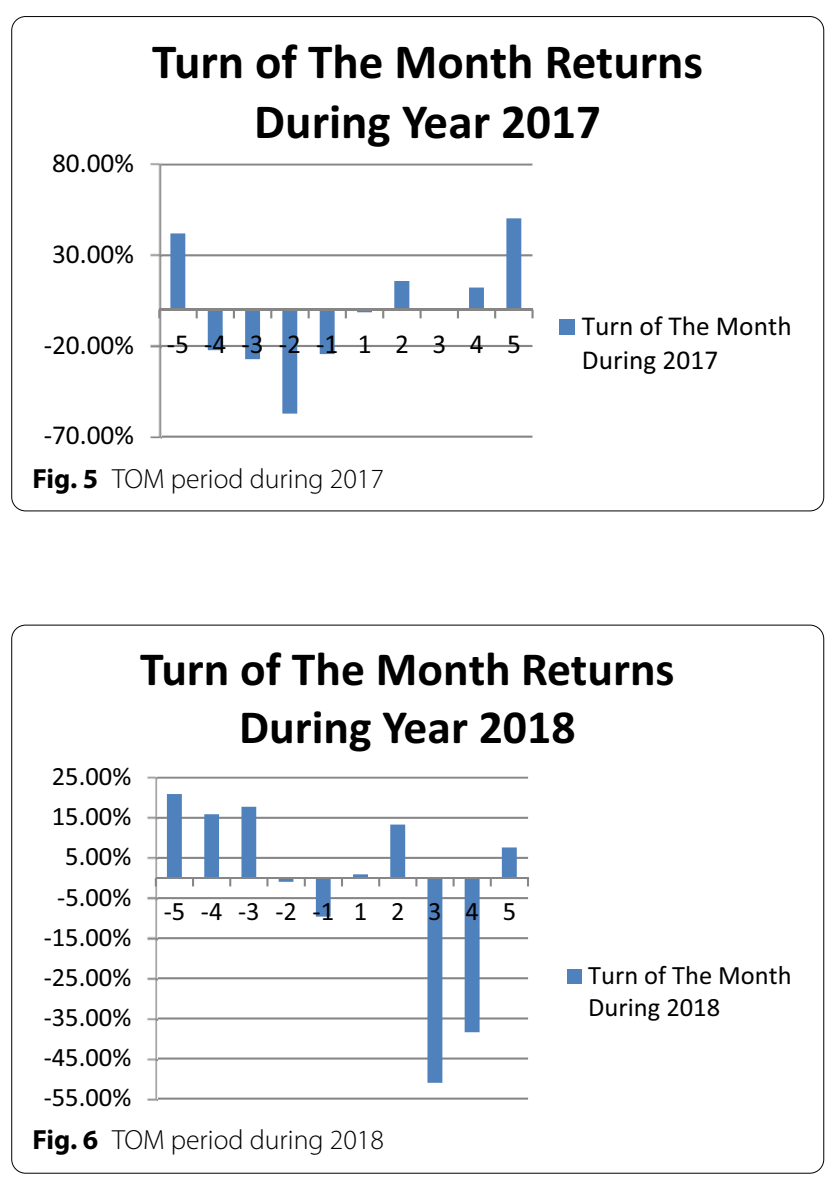

Here, $\mathrm{KSE}_{100} R$ is dependent variable, which represents the returns of "KSE-100 Index". TMD (turn-ofthe-month dummy) is an independent variable, which is measured by a dummy that takes the value $=1$, if KSE-100 stock returns lie within a "turn-of-themonth" period; otherwise $=0$. We perform t-test of means and linear regression analysis on the above econometric equation in order to explore whether "turn-of-the-month-effect" exists in Pakistani stock market.

\section{Data analysis techniques}

Data analysis techniques intensify the target measurements by using pre-existing statistical data utilizing computational techniques. Techniques used in this study are as follows:

- Descriptive statistics

- T-test of means

- Regression analysis

\section{Results and discussion}

\section{Descriptive/summary statistics}

We report the descriptive statistics of the daily "KSE100 Index" returns in Table 1. We observe that the mean return during the whole sample period 2013-2018 is $0.058 \%$, with a maximum return of $4.51 \%$ and a minimum value of $-4.65 \%$.

Table 1 further shows the year wise summary statistics of daily "KSE-100 Index" returns. Row 2 (Table 1) reports the descriptive statistics for year 2013. We can see that the average value of daily "KSE-100 Index" returns was $0.17 \%$, with a minimum of $5.87 \%$ and a maximum of negative $3.15 \%$. Row 3 (Table 1) indicates the behavior of daily "KSE-100 Index" stock returns in year 2014. The mean return was $0.098 \%$, with a minimum of negative $4.45 \%$ and a maximum of $2.85 \%$.

Row 4 (Table 1) explains the summary of daily "KSE100 Index" stock returns in year 2015. The mean was $0.012 \%$, with a minimum of negative $4.11 \%$ and a maximum of $4.51 \%$. Row 5 (Table 1) determines the behavior of daily "KSE-100 Index" stock returns in year 2016. The mean was $0.15 \%$, with a minimum of negative $2.21 \%$ and a maximum of $3.52 \%$. Row 6 (Table 1) shows the behaviour of daily "KSE-100 Index" stock returns in year 2017. The mean was negative $0.059 \%$, with a minimum of negative $4.65 \%$ and a maximum of $3.22 \%$. Last row of Table 1 indicates the behavior of daily "KSE-100 Index" stock returns in year 2018. The mean was negative $0.02 \%$, with a minimum of negative $3.38 \%$ and a maximum of $4.12 \%$.

\section{T-test of means}

Table 2 reports the $T$-test of means to preliminary confirm the presence of the "turn-of-the-month-effect" in the KSE-100 index for 2013-2018. This test is conducted to determine whether there is a significant difference between turn-of-the-month and rest-of-the-month periods. The results in Table 2 clearly describe that the mean during turn-of-the-month period is 0.14 as compared to the mean during rest-of-the-month period which is 0.01 
Table 1 Summary statistics for "KSE-100 Index" returns

\begin{tabular}{|c|c|c|c|c|c|c|c|c|}
\hline Period & $\mathrm{N}$ & Mean & Median & SD & Kurt & Skew & Min & Max \\
\hline 2013-2018 & 1505 & 0.058 & 0.0523 & 0.9417 & 2.710 & -0.308 & -4.65 & 4.51 \\
\hline 2013 & 251 & 0.1743 & 0.176 & 0.927 & 1.254 & -0.36 & 5.87 & -3.15 \\
\hline 2014 & 252 & 0.098 & 0.090 & 0.819 & 4.229 & -0.569 & -4.455 & 2.856 \\
\hline 2015 & 252 & 0.012 & -0.0 .13 & 0.905 & 4.594 & -0.265 & -4.111 & 4.517 \\
\hline 2016 & 252 & 0.152 & 0.106 & 0.715 & 2.812 & 0.367 & -2.21 & 3.52 \\
\hline 2017 & 251 & -0.059 & -0.014 & 1.145 & 1.876 & -0.472 & -4.653 & 3.224 \\
\hline 2018 & 247 & -0.029 & -0.118 & 1.059 & 1.415 & 0.141 & -3.385 & 4.126 \\
\hline
\end{tabular}

Notes: This table reports the general statistics of daily "KSE-100 Index" returns. N represents number of observation, SD indicates standard deviation of the daily "KSE100 Index" returns

Table 2 T-test of means for "turn-of-the-month-effect" on overall sample

\begin{tabular}{lllll}
\hline & TOM & ROM & Difference & Fraction \\
\hline Mean & 0.14 & 0.01 & 0.12 & 0.08 \\
SD & 0.32 & 0.30 & 0.08 & \\
t-stat & $3.30^{* * *}$ & 0.34 & $2.32^{* * *}$ & \\
\hline
\end{tabular}

Notes: The table reports mean values of daily "turn-of-the-month" and "rest-ofthe-month" returns of "KSE-100 Index" for overall sample. Moreover, t-statistics is also reported by keeping the hypothesized mean equal to zero. 4th column is the difference between "turn-of-the-month" and "rest-of-the-month". Last column is of fraction which is computed by dividing the total return generated during "turn-of-the-month" period by aggregate return of the overall "KSE-100 Index". $\left.{ }^{*} p<0.1 ;{ }^{* *} p<0.05 ;{ }^{* * *} p<0.01\right)$

indicating the presence of "turn-of-the-month-effect" in Pakistani stock market during 2013-2018. To dig out further, we run year-wise t-test of means (Tables 3, 4, 5, 6, 7, 8).

Table 3 reports the results of t-test of means during year 2013. The findings show that, in year 2013, the average value of daily "KSE-100 Index" returns for the "turn-of-the-month" period was 0.34 as compared to the average during "rest-of-the-month" period that is 0.13 , which clearly indicates the presence of "turn-of-themonth-effect" in the year 2013.

Table 4 shows mean values of daily "turn-of-themonth" and "rest-of-the-month" returns of "KSE-100 Index" for Year 2014. Here, mean value for turn-of-themonth period is 0.492 as compared to the mean value of rest-of-the-month period that is 0.003 . This, again, clarifies that the "KSE-100 Index" experienced much better returns in 2014 during the turn-of-the-month period.

Table 5 shows the results of t-test of means during year 2015. The findings show that, in year 2015, the mean value for the turn-of-the-month period was 0.435 as compared to the mean value of rest-of-the-month period which is negative 0.084 . Year 2015 experienced negative returns in rest-of-the-month period and this clearly indicate the presence of "turn-of-the-montheffect" in the year 2015.
Table 6 indicates the results for "KSE-100 Index" returns during the year of 2016. Here, mean for the turn-of-the-month period and the rest-of-the-month period is 0.461 and 0.077 respectively. This clearly shows that the "turn-of-the-month" causes the stock returns to increase.

Table 7 shows the average returns for the year 2017. Here, the mean value for the turn-of-the-month period is 'negative 0.056 ' as compared to the mean value of rest-of-the-month period that is of 'negative 0.060'. As predicted earlier through graphical depiction, that the "turn-of-the-month" disappears in 2017.

Table 8 reports the results of $t$-test of means during year 2018. The findings show that, the average value of "KSE-100" index stock returns during the "turn-of-themonth" period is of ' -0.059 ' as compared to the average value during the rest-of-the-month period which is of ' -0.020 '. The results show the absence of the "turnof-the-month" effect also in 2018.

\section{Regression analysis}

The study conducted a linear regression analysis to determine the returns of stocks from the period of January 2013 to December 2018. Table 9 reports the results of linear regression analysis on our overall sample.

The findings (reported in Table 9) indicate the presence of "turn-of-the-month-effect" in Pakistani stock market during our overall sample period as indicated by positive and significant coefficient of 0.259 of TMD ("turn-of-themonth-effect" dummy). These findings robust confirm the results of our t-test of means.

Table 10 reports the results of year-wise regression analysis from 2013 to 2018. In year 2013, we can notice that the value of TMD is 0.249 which is statistically significant at $10 \%$ level, indicating the presence of "turn-ofthe-month-effect" in Pakistani stock market.

For the year 2014, the value of TMD is 0.454 which is statistically significant at $1 \%$ level, stipulating the existence of "turn-of-the-month-effect" in Pakistani stock market.Similarly, we can observe the 
Table 3 T-test of means for "Turn-of-the-Month-Effect" of year 2013

\begin{tabular}{lllll}
\hline & TOM & ROM & Difference & Fraction \\
\hline Mean & 0.34 & 0.13 & 0.21 & 0.36 \\
SD & 1.02 & 0.90 & 0.47 & \\
$t$-stat & $2.31^{* *}$ & $2.15^{* *}$ & 1.39 & \\
\hline
\end{tabular}

Notes: The table reports mean values of daily "turn-of-the-month" and "rest-ofthe-month" returns of "KSE-100 Index" for Year 2013. Moreover, t-statistics is also reported by keeping the hypothesized mean equal to zero. 4th column is the difference between "turn-of-the-month" and "rest-of-the-month". Last column is of fraction which is computed by dividing the total return generated during "turn-of-the-month" period by aggregate return of the overall "KSE-100 Index". $\left({ }^{*} p<0.1 ;{ }^{* *} p<0.05 ;{ }^{* * *} p<0.01\right)$

Table 4 T-test of means for "Turn-of-the-Month-Effect" of year 2014

\begin{tabular}{lllll}
\hline & TOM & ROM & Difference & Fraction \\
\hline Mean & 0.492 & 0.003 & 0.489 & 0.94 \\
SD & 0.90 & 0.76 & 0.48 & \\
t-stat & $3.74^{* * *}$ & 0.05 & $3.82^{* * *}$ & \\
\hline
\end{tabular}

Notes: The table reports mean values of daily "turn-of-the-month" and "rest-ofthe-month" returns of "KSE-100 Index" for Year 2014. Moreover, t-statistics is also reported by keeping the hypothesized mean equal to zero. 4th column is the difference between "turn-of-the-month" and "rest-of-the-month". Last column is of fraction which is computed by dividing the total return generated during "turn-of-the-month" period by aggregate return of the overall "KSE-100 Index". $\left({ }^{*} p<0.1 ;{ }^{* *} p<0.05 ; * * * p<0.01\right)$

Table 5 T-test of means for "Turn-of-the-Month-Effect" of year 2015

\begin{tabular}{lllll}
\hline & TOM & ROM & Difference & Fraction \\
\hline Mean & 0.435 & -0.084 & 0.519 & 6.65 \\
SD & 1.06 & 0.83 & 0.66 & \\
$t$-stat & $2.82^{* * *}$ & -1.43 & $3.66^{* * *}$ & \\
\hline
\end{tabular}

Notes: The table reports mean values of daily "turn-of-the-month" and "rest-ofthe-month" returns of "KSE-100 Index" for Year 2015. Moreover, t-statistics is also reported by keeping the hypothesized mean equal to zero. 4th column is the difference between "turn-of-the-month" and "rest-of-the-month". Last column is of fraction which is computed by dividing the total return generated during "turn-of-the-month" period by aggregate return of the overall "KSE-100 Index". $\left({ }^{*} p<0.1 ;{ }^{* *} p<0.05 ;{ }^{* * *} p<0.01\right)$

"turn-of-the-month-effect" presence during 2015 and 2016 as indicated by their statistically significant coefficients (at $1 \%$ level) of 0.47 and 0.38 , respectively.

Interestingly, the values of TMDs during 2017 and 2018 are insignificant and negative 0.04 and negative 0.07 , respectively, indicating that the "turn-of-the-montheffect" vanishes during this period.

The regression analysis results summarize that "turnof-the-month-effect" exists in the Pakistani stock market for the overall sample. However, while examining the year-wise samples, we observe that the effect of the "turn-of-the-month" anomaly disappears for 2017 and
Table 6 T-test of means for "Turn-of-the-Month-Effect" of year 2016

\begin{tabular}{lllll}
\hline & TOM & ROM & Difference & Fraction \\
\hline Mean & 0.461 & 0.077 & 0.383 & 0.57 \\
SD & 0.77 & 0.68 & 0.36 & \\
$t$-stat & $4.12^{* * *}$ & 1.62 & $3.41^{* * *}$ & \\
\hline
\end{tabular}

Notes: The table reports mean values of daily "turn-of-the-month" and "rest-ofthe-month" returns of "KSE-100 Index" for Year 2016. Moreover, t-statistics is also reported by keeping the hypothesized mean equal to zero. 4 th column is the difference between "turn-of-the-month" and "rest-of-the-month". Last column is of fraction which is computed by dividing the total return generated during "turn-of-the-month" period by aggregate return of the overall "KSE-100 Index". ( $p<0.1 ;{ }^{* *} p<0.05 ;{ }^{* * *} p<0.01$ )

Table 7 T-test of means for "Turn-of-the-Month-Effect" of year 2017

\begin{tabular}{lccll}
\hline & TOM & ROM & Difference & Fraction \\
\hline Mean & -0.056 & -0.060 & 0.004 & 0.18 \\
SD & 1.32 & 1.10 & 0.72 & \\
t-stat & -0.29 & -0.77 & 0.02 & \\
\hline
\end{tabular}

Notes: The table reports mean values of daily "turn-of-the-month" and "rest-ofthe-month" returns of "KSE-100 Index" for Year 2017. Moreover, t-statistics is also reported by keeping the hypothesized mean equal to zero. 4th column is the difference between "turn-of-the-month" and "rest-of-the-month". Last column is of fraction which is computed by dividing the total return generated during "turn-of-the-month" period by aggregate return of the overall "KSE-100 Index". $\left({ }^{*} p<0.1 ;{ }^{* *} p<0.05 ;{ }^{* * *} p<0.01\right)$

2018. In conclusion, we try to explain the appearance and disappearance of this anomaly.

\section{Conclusions}

This research intended to examine whether the "KSE-100 Index" stock returns represented a "turn-of-the-montheffect" in Pakistan. The study used the data from January 2013 to December 2018. It employed a $t$-test of means and linear regression model to test the existence of the "turn-of-the-month-effect" in the Pakistani stock market. We report that the "turn-of-the-month-effect" is significant only during 2013-2016, while it vanishes for 2017 and 2018, and suggest that some of the calendar anomalies may disappear during stock market crisis times.

The evidence of the presence of the "turn-of-themonth-anomaly" for 2013-2016 refers to the "liquidity fund hypothesis," as Ogden [28] argued that the stock market gain momentum during the "turn-of-the-monthperiod" because the investors love to reinvest their funds quickly (earned through salaries' remittances, interest rate and dividend payments, etc.) into more liquid stocks rather than the fixed deposits.

Discussing the disappearance of the "turn-of-themonth" effect in the "KSE-100" index for 2017 and 2018 
Table 8 T-test of means for "Turn-of-the-Month-Effect" of year 2018

\begin{tabular}{lcccc}
\hline & TOM & ROM & Difference & Fraction \\
\hline Mean & -0.059 & -0.020 & -0.039 & 0.38 \\
SD & 0.96 & 1.08 & 0.12 & \\
$t$-stat & -0.42 & -0.26 & 0.22 & \\
\hline
\end{tabular}

Notes: The table reports mean values of daily "turn-of-the-month" and "rest-ofthe-month" returns of "KSE-100 Index" for Year 2018. Moreover, t-statistics is also reported by keeping the hypothesized mean equal to zero. 4th column is the difference between "turn-of-the-month" and "rest-of-the-month". Last column is of fraction which is computed by dividing the total return generated during "turn-of-the-month" period by aggregate return of the overall "KSE-100 Index". $\left({ }^{*} p<0.1 ;{ }^{* *} p<0.05 ;{ }^{* * *} p<0.01\right)$

Table 9 Linear regression on overall sample

\begin{tabular}{ll}
\hline & $\begin{array}{l}\mathrm{KSE}_{100} \boldsymbol{R} \\
\text { (dependent } \\
\text { variable) }\end{array}$ \\
\hline TMD & $0.259^{* * *}$ \\
Intercept & $(4.22)$ \\
$N$ & 0.008 \\
F-statistic & $(0.33)$ \\
p value (F-statistic) & 1505 \\
\hline
\end{tabular}

Notes: This table explains the results of linear regression between "turn-ofthe-month-effect" dummy (independent variable) and "KSE-100 Index" returns (dependent variable). TMD represents "turn-of-the-month-effect" dummy, and $R$ denotes "KSE-100 index" returns. * ***, and *** denote statistical significance at $10 \%, 5 \%$, and $1 \%$ levels, $t$-statistics is presented in parenthesis. $N$ denotes the number of observations

seems to be an interesting rather critical task. Theoretically, as discussed by Wong et al. (2006), the suspension of some calendar anomalies may be because of the fact that shareholders have now become entirely aware of taking advantage of these anomalies. Therefore, they are unable to induce abnormal returns by cashing on these anomalies. As more and more shareholders utilize this effect, it becomes difficult to take advantage of these anomalies after their recognition. For instance, after recognizing the "turn-of-the-month effect," the shareholders who anticipate the stock returns to increase in the last and first few days of the month will then purchase before the end of the month and sell at the start of the particular month.

Systematically, since its inception, Pakistan's stock market has been continuously inheriting political uncertainty risk. Similarly, the years 2017 and 2018 were not satisfactory in terms of politics, and the events like "Panama Leaks" cause the disqualification of Mr. Nawaz Sharif (Ex-Prime Minister). Pakistan, where crony capitalism is on the rise [15], a prime political figure's disqualification will surely jolt the stock market. Accordingly, the stock market of Pakistan showed a decline of 20\% in year 2017 and was declared as Asia's worst performer. The media reported that this stock market depression is expected to continue until the general elections in 2018 (Express 2017). During these years, Pakistan's foreign exchange reserves decreased by $20 \%$, and the current account deficit increased by 1.56-times. Sector-wise performance was also not encouraging. The automobile sector's profitability dropped by $15 \%$, the cement sector experienced a loss of $49 \%$, and the banking sector showed a negative return in the outgoing year. When such adverse effects and uncertainty can turn the best player (KSE-100 index) in 2016 into the worst one in 2017, then we may expect that this might be the reason for the temporary disappearance of the "turn-of-the-month" anomaly.

Given the disparity in the market structures, corporation's ownership structures, and payment patterns across developing and developed nations, it is not necessary that in all of the stock markets, cash flows accumulate in the last few trading days of a calendar month [40]. These explanations require imminent investigation to dig out the mechanism of the "turn-of-themonth-effect". To recapitulate, we recommend further

Table 10 Linear regression year-wise

\begin{tabular}{lllllll}
\hline & $\mathbf{2 0 1 3}$ & $\mathbf{2 0 1 4}$ & $\mathbf{2 0 1 5}$ & $\mathbf{2 0 1 6}$ & $\mathbf{2 0 1 7}$ & $\mathbf{2 0 1 8}$ \\
\hline \multirow{2}{*}{ TMD } & R (Dependent Variable) & & & & \\
& $0.249^{*}$ & $0.454^{* * *}$ & $0.476^{* * *}$ & $0.38^{* * *}$ & -0.04 & -0.07 \\
Intercept & $(1.67)$ & $(3.57)$ & $(3.34)$ & 3.41 & -0.23 & -0.06 \\
& $0.136^{* *}$ & 0.003 & -0.08 & 0.07 & -0.75 & -0.02 \\
$N$ & $(2.08)$ & $(0.05)$ & -1.36 & 258 & 250 & 0.27 \\
F-statistic & 253 & 251 & 251 & 11.67 & 0.055 & 0.181 \\
$p$ value (F-statistic) & 2.81 & 12.78 & 11.15 & 0.0007 & 0.813 & 0.67 \\
\hline
\end{tabular}

Notes: This table indicates the year-wise results of linear regression between "turn-of-the-month-effect" dummy (independent variable) and "KSE-100 Index" returns (dependent variable). TMD represents "turn-of-the-month-effect" dummy, and $R$ denotes "KSE-100 Index" returns. * **, and *** denote statistical significance at 10\%, $5 \%$, and $1 \%$ levels, $t$-statistics is presented in parenthesis. $N$ denotes the number of observations 
comparative work examining the sub-samples, including crises versus regular times with a broader sample size in a similar setting and the other stock markets.

\section{Abbreviations}

EMH: Efficient Market Hypothesis; KSE: Karachi Stock Exchange; KSEIR: Karachi Stock Exchange Index Return; LDC: Least Developed Country; PSX: Pakistan Stock Exchange; ROM: Rest of the month; SD: Standard Deviation; TOM: Turn of the month; TMD: Turn of the month dummy; TOMR: Turn of the month returns; ROMR: Rest of the month returns.

\section{Acknowledgements}

Not applicable.

\section{Authors' contributions}

MSI is the principle author. He along with SK (corresponding author) developed the theme of this research. He also wrote the abstract, introduction, and conclusion sections of this article. SK also assisted in performing data analysis, composition of various graphs, and tables. NB helped in writing the research methods section of this study, and IA has completed the results and discussion section. All authors have read and approved the manuscript.

\section{Funding}

This study has no funding source from any supportive organization or any foundation.

\section{Availability of data and material}

This study used secondary sources of data available on Yahoo Finance.

\section{Declarations}

\section{Competing interests}

The authors declare that they have no competing interests.

\section{Author details}

${ }^{1}$ Faculty of Management Sciences, Foundation University Islamabad, Islamabad, Pakistan. ${ }^{2}$ Fatima Jinnah Women University, Rawalpindi, Pakistan. ${ }^{3}$ Department of Economics and Business Administration, University of Education, Lahore, Pakistan.

Received: 6 November 2020 Accepted: 25 July 2021

Published: 28 September 2021

\section{References}

1. Agrawal A, Tandon K (1994) Anomalies or illusions? Evidence from stock markets in eighteen countries. J Int Money Finance 13(1):83-106

2. Al-Jarrah IM, Khamees BA, Qteishat IH (2011) The turn of the month anomaly in Amman stock exchange: evidence and implications. J Money Invest Bank 21:5-11

3. Alrabadi D, AL-Qudah K (2012) Calendar anomalies: the case of Amman stock exchange. Int J Bus Manage 7(24):120-127. https://doi.org/10.5539/ ijbm.v7n24p120

4. Anjum S (2020) Impact of market anomalies on stock exchange: a comparative study of KSE and PSX. Future Bus J 6(1):1-11

5. Arendas P, Kotlebova J (2019) The turn of the month effect on CEE Stock Markets. Int J Financ Stud 7(4):57

6. Ariel RA (1987) A monthly effect in stock returns. J Financ Econ 18(1):161-174

7. Arsad ZB, Chuah SAS, Nordin SNM (2011) Predictability of turn-of-themonth effect at stock markets in Malaysia, South Korea and Japan. South Korea and Japan (August 21, 2011)

8. Aziz T, Ansari VA (2018) The turn of the month effect in Asia-Pacific markets: new evidence. Glob Bus Rev 19(1):214-226

9. Booth GG, Kallunki JP, Martikainen T (2001) Liquidity and the turn-ofthe-month effect: evidence from Finland. J Int Financ Mark Inst Money 11(2):137-146
10. Broman MS, Shum P (2018) Relative liquidity, fund flows and short-term demand: evidence from exchange-traded funds. Financ Rev 53(1):87-115

11. Cadsby CB, Ratner M (1992) Turn-of-month and pre-holiday effects on stock returns: Some international evidence. J Bank Finance 16(3):497-509

12. Chancharat S, Maporn S, Phuensane P, Chancharat N (2020) Volatility of holiday effects in Thai stock market. Kasetsart J Soc Sci 41(2):401-406

13. Fama EF (1970) Efficient capital markets: a review of theory and empirical work. J Finance 25(2):383-417

14. Fosback NG (1976) Stock market logic: a sophisticated approach to profits on Wall Street. Inst Econom Res

15. Isran AM (2020). Rising crony capitalism. The News. Retrieved from https://www.thenews.com.pk/

16. Jebran K, Chen S (2017) Examining anomalies in Islamic equity market of Pakistan. J Sust Finance Invest 7(3):275-289

17. Karmakar M, Chakraborty M (2000) A trading strategy for the Indian stock market: analysis and implications. Vikalpa 25(4):27-38

18. Kayacetin V, Lekpek S (2016) Turn-of-the-month effect: New evidence from an emergingstock market. Finance Res Lett 18:142-157

19. Kohers T, Patel JB (1999) A new time-of-the-month anomaly in stock index returns. Appl Econ Lett 6(2):115-120

20. Kunkel RA, Compton WS, Beyer S (2003) The turn-of-the-month effect still lives: the international evidence. Int Rev Financ Anal 12(2):207-221

21. Li J, Feng X, Zhang Y (2020) Month-end effect on Chinese stock returns: explanation of the liquidity hypothesis. Asia-Pac J Account Econ 1-16

22. Li-Cheng FENG (2003) Month-of-the-year effect" and" turn-of-the-month effect" in the Chinese Stock Markets. Policy-making Reference, 1

23. Maher D, Parikh A (2013) The turn of the month effect in India: a case of large institutional trading pattern as a source of higher liquidity. Int Rev Financ Anal 28:57-69

24. Mangala D, Sharma SK (2007) Are there monthly and turn-of-the-month effects in Indian Stock Market?: evidence and implications. Paradigm 11(2):16-22

25. Martikainen T, Perttunen J, Ziemba TW (2012) The Turn-of-the-montheffect in the world's stock markets, January 1988-January 1990. In: Calendar anomalies and arbitrage, Chapter 15. World Scientific, Hackensach, pp 355-363. Retrieved from https://doi.org/10.1142/9789814405461_0015

26. McConnell JJ, Xu W (2008) Equity returns at the turn of the month. Financ Anal J 64(2):49-64

27. McGuinness PB (2006) 'Turn-of-the-month' return effects for small cap Hong Kong stocks. Appl Econ Lett 13(14):891-898

28. Ogden JP (1990) Turn-of-month evaluations of liquid profits and stock returns: a common explanation for the monthly and January effects. J Finance 45(4):1259-1272

29. Oğuzsoy CB, Güven S (2006) Turn of the month and turn of the month surrounding days' effects in Istanbul stock exchange. J Emerg Mark Finance 5(1):1-13

30. Plastun A, Sibande X, Gupta R, Wohar ME (2020) Halloween effect in developedstock markets: a historical perspective. Int Econ 161:130-138

31. Poshakwale S (1996) Evidence on weak form efficiency and day of the week effect in the Indian stock market. Finance India 10(3):605-616

32. Quayyoum S, Asad M, Simonetti B, Lau E (2017) Calendar anomalies in Pakistan stock market. Electron J Appl Stat Anal 10(2):583-598

33. Siddiqui S (2017) Pakistan's stock market: from Asia's best to Asia's worst. The Express. Retrieved from https://tribune.com.pk/

34. Silva PM (2010) Calendar "anomalies" in the Portuguese stock market. Invest Anal J 39(71):37-50

35. Singh G, Bhattacharjee K, Kumar S (2020) Turn-of-the-month effect in three major emerging countries. Manag Finance 47(4):555-569

36. Tadepalli MS, Jain RK, Metri ABA (2021) An inquiry into the persistence of turnof-the-month effect on stock markets in India: insights and perspectives on a seasonal anomaly. Bus Perspect Res. https://doi.org/10.1177/ 2278533721994713

37. Vasileiou $E$ (2014) Turn of the month effect and financial crisis: a new explanation from the Greek stock market (2002-2012). Theor Appl Econ 21(10):599

38. Wuthisatian R (2021) An examination of calendar anomalies: evidence from the Thai stock market. J Econ Stud. https://doi.org/10.1108/ JES-06-2020-0298

39. Zhang N (2020) The cause of the turn-of-month effect in the Chinese security market: an empirical study of the liquidity hypothesis. Retrieved from https://tesi.luiss.it/id/eprint/27932 
40. Ziemba WT (1991) Japanese security market regularities: monthly, turnof-the-month and year, holiday and golden week effects. Jpn World Econ 3(2):119-146

41. Zwergel B (2010) On the exploitability of the turn-of-the-month effect: an international perspective. Appl Financ Econ 20(11):911-922

\section{Publisher's note}

Springer Nature remains neutral with regard to jurisdictional claims in published maps and institutional affiliations.
Submit your manuscript to a SpringerOpen ${ }^{\circ}$ journal and benefit from:

- Convenient online submission

- Rigorous peer review

- Open access: articles freely available online

- High visibility within the field

Retaining the copyright to your article

Submit your next manuscript at $\boldsymbol{\nabla}$ springeropen.com 